Revue de l'Institut des langues et cultures

d'Europe, Amérique, Afrique, Asie et Australie

39 | 2020

Les humanités numériques dans une perspective internationale : opportunités, défis, outils et méthodes

\title{
Perspectives on the Identification and Description with Artificial Intelligence for Open Access Data of Artistic Historical Bookbindings for Researchers
}

Perspectives sur l'identification et la description avec intelligence artificielle

pour des données en accès libre de reliures historiques artistiques destinées aux chercheurs

Perspectivas en la identificación y descripción de las encuadernaciones artísticas históricas con inteligencia artificial para el acceso abierto a los datos

María Helena Vargas Mejía

\section{(2) OpenEdition}

\section{Electronic version}

URL: http://journals.openedition.org/ilcea/9066

DOI: $10.4000 /$ ilcea.9066

ISSN: 2101-0609

Publisher

UGA Éditions/Université Grenoble Alpes

Printed version

ISBN: 978-2-37747-174-4

ISSN: 1639-6073

Electronic reference

María Helena Vargas Mejía, «Perspectives on the Identification and Description with Artificial Intelligence for Open Access Data of Artistic Historical Bookbindings for Researchers ", ILCEA [Online], 39 | 2020, Online since 03 March 2020, connection on 10 October 2020. URL : http:// journals.openedition.org/ilcea/9066 ; DOI : https://doi.org/10.4000/ilcea.9066

This text was automatically generated on 10 October 2020

(C) ILCEA 


\section{Perspectives on the Identification and Description with Artificial Intelligence for Open Access Data of Artistic Historical Bookbindings for Researchers}

Perspectives sur l'identification et la description avec intelligence artificielle pour des données en accès libre de reliures historiques artistiques destinées aux chercheurs

Perspectivas en la identificación y descripción de las encuadernaciones artísticas históricas con inteligencia artificial para el acceso abierto a los datos

María Helena Vargas Mejía

\section{Introduction}

1 The ancient books ${ }^{1}$ are objects of interest for a variety of fields of study because of the information they offer about the past. The characteristics of the ancient books are a permanent source of information that is enriched and exponentially enhanced by the multiple interpretative possibilities which emerge from them through studying and analyzing them in relation to other historical testimonies, within different dimensions and contexts of time.

2 The bookbinding, on the other hand, is scarcely explored in comparison with the studies that are made about written and graphic records. It is the part valued, essentially, for its protective function of the written record, but it lacks further study when it has been decorated like blind-tooled or gilded. However, in general, they have generated interest and are considered significant for historical research, as a source and evidence of the past, since bookbindings reflect considerations that affect and 
enhance the traditional study of written information. For this reason, it has become evident the need to carry out detailed studies with greater assiduity on these bookbindings, which are called as artistic historical bookbindings by the Documentation Sciences ${ }^{2}$.

There are still few reports in Humanities, Historiographic Techniques and Sciences ${ }^{3}$, Conservation and Restoration and Information and Documentation Sciences research about the ancient book with artistic bindings, which preferably consider its material aspects-as supports and techniques used to made them-over the written or graphic information traditionally studied. The results presented indicate that they provide information that allows us to solve historical gaps, such as dating and geographical origin. They have allowed formulating more precise hypotheses or concrete results in philology, for example; of relations between historical entities and other documentary sources, the transfer of knowledge, and links between literary traditions and the techniques and materials constituting the sources (Martinez Manzano, 2014).

There is a range of possibilities for interpreting the past, supported by the study of decorated bindings. We reflect on the use of artificial intelligence, as a strategy and tool in virtual environments, for the automated identification and description of artistic historical book bindings, and for the relational handling of the large amount of data that is derived from them, hoping these historical evidences empower the perspectives and fields of investigation and the multidisciplinary articulation (Rojas, 2012).

\section{Historical context and analysis of the ancient bookbindings}

We can say briefly that, traditionally, the study, analysis and value of bookbindings were mainly considered for their functional perspective, and not as relevant information on its own. This caused the replacement of the ancient bookbindings over the time by newer ones, when they weren't serving their main function: protecting the written content.

The profusely decorated bookbindings had been recognized for their aesthetic characteristics, similar to a piece of art, and they draw the attention of the researcher when help in the identification of trades related to the written part, providing context data of an era.

7 These perceptions on bookbinding in general have been changing since it was shown that the destruction or alteration of physical structures, such as bindings, has affected the historiographic exercise (Szirmai, 1999) ${ }^{4}$. However, its characteristics have not been fully recognized or identified by disciplines that could be sensitive to them, such as History, the History of Art, the History of Book, the History of Writing, Bibliographic Heritage, national libraries and, in general, the Humanities that depend on the study of the ancient book.

\section{The unlinked universe of artistic historical bookbindings}

The origin of many of the techniques of elaboration of materials, of the producing entities, of their relations with other past and similar testimonies, is yet to be discovered. It has been understood that a large part of the information, by the way it was designed and the way the techniques used for the creation of its structures have been conceived, has disappeared with the loss of the bindings ${ }^{5}$. 
Over the centuries, trades for the development of supports, supplies and texts around the ancient book developed. There were also offices for the creation of artistic bindings, in addition to the work of bookbinder, typographer, engraver and gilder, among those already recognized. It is possible that there were specialized officesadorners and jewelers-that created luxurious bindings as we know existed, the book repairman ${ }^{6}$.

10 The historic and the editorial production from the 15th century, the disciplines we already mention and the specialty in bibliographic documents within the conservation and restoration discipline, supported by chemistry and microbiological sciences, are some of the main fields that are interested first hand with the study of the materiality of the ancient book and, therefore, require information about the bindings. These disciplines, in turn, with their studies offer information about them that have not been articulated in a scenario we can project as an interactive and dynamic open data cross reference option that can be managed in a digital repository (Rojas, 2012)7.

11 The disciplines interested in the subject of the ancient book, affiliated with specialized work, were developed in isolation from the fields we have previously mentioned, for various reasons (Rojas, 2012: 77). Philology and Textual Criticism rely mainly on the work of Paleography, Sigilography and Codicology, but not systematically on Conservation and Restoration. They take from the Historiographic Sciences and Techniques what they require for their perspective of study. On the contrary, Conservation and Restoration, in order to save the source of the irreparable loss of its informative potential, should follow, always and closely, the studies and results of Philology, Textual Criticism, Paleography, Sigilography and Codicology; for these disciplines advance towards the determination of the intervention criteria, and the identification of historical values that must be preserved. But we know that sometimes abstains due to lack of resources and time, or the inability to understand the information produced by academics, therefore putting at risk the informative potential of the object that is intervened. And this outlook was made only with the most popular and evident disciplines today. In the next chapters we will continue adding up other necessary considerations.

\section{Artistic Historical Bookbindings as an underrated field of study}

12 For a couple of decades, the historical artistic bindings have been studied and described in their decorative features ${ }^{8}$, but only the main aspects of the materials and techniques were considered, disconnected from information about the origin, the content of the book and the fields that were part of the formulation of the data9.

The lack of knowledge about the decorative aspect, and its implications for academic research, impacts the way in which documents are perceived and presented for access to the researcher.

Today we can find a few catalogs and repositories that offer descriptive elements of the physical characteristics, such as the supports decorated with the marble technique and the forms associated with certain decorative styles already dated (Carpallo, 2017). Nevertheless, some of them offer these data avoiding the production entities, even though it is explicit in the book. The user is left with the task of its identification and value. 
It is also frequent that material information about books,-like data on weight, descriptions of texture and structural tensions-, is not presented even when this information was detected in conservation and restoration processes. In general, this kind of data is not public, normalized or linked to the ancient book collections descriptions ${ }^{10}$ even if this kind of information is relevant to material research of books as well as to analyze and collate relations between bookbindings, internal structures and the content of the books.

However, we also found specialized institutions-like the University of Arts of London and it's Ligatus Research Centre, the British Library, the Bibliothèque Nationale de France, the Library of Congress, among others-, where artistic book bindings and, in general, material aspects of the books are seen as relevant and now documented in some of their aspects, changing the perception about them and therefore creating more interest in this matter. This is possible because the catalogs and repositories are offering the information of ancient books pointed to physical aspects like bookbindings (Carpallo, 2001) ${ }^{11}$.

\section{The terminology of multidisciplinary communication}

Communication is necessary between disciplines to make an effective articulation of material studies about ancient books (Rojas, 2012: 76-77) ${ }^{12}$. We share the idea that this is an aspect we must attend in order to coordinate and articulate the isolated and scattered data related to $\mathrm{it}^{13}$.

We believe we can build channels, with artificial intelligence (AI) and virtual environments, to facilitate the necessary multi and transdisciplinary communication for the study of our topic of interest and the dispersed information related to it.

\section{Contexts, visualization and access to bookbinding data}

19 In this reflection, we also consider the different types of data around the historical artistic bindings. These in turn are evidence of the existing relationships between these and other forms of the book, and that therefore generate a need to connect the fields of study specialized in each one of them, the interpretation of these bindings-and of the ancient book in general. Thus, these fields could be made more dynamic and the frontiers of current studies could be widening.

20 In consequence, putting into "dialogue" the disciplines and the data they produce, as a method of exploiting interpretative and informative possibilities, is an immeasurable task, if it is done by traditional means ${ }^{14}$. For that reason, the project needs to attend the communication aspect between specialized disciplines, by the reunion of data contextualized in their various aspects of origin-chronological, geographical and from the field of expertise where it was produced or detected. We believe that it is crucial to identify the origin of the basic data and how and where it could have been transformed with the interpretation that has been made of it when turning it into a coded data $a^{15}$.

21 The transformation of the original data is not always easily perceptible or visible and, therefore, much less tangible. Having the essential data to perform an analysis of the information is a matter that depends on how the information is offered. Also, their transformation isn't clear to the researcher unless it is given explicitly, even where there was loss, despite the efforts in the construction of a traceability system. 


\section{our project considered also the use of AI to identify and describe automatic
considerable amount of information related between them. intelligence} lack of studies, the dispersed information, the communication for the obliged articulation, and the terminology as a matter for the multidisciplinary confluence; the contexts as inescapable support and the access by visualization of data. All those elements, in one way or another, are tangible by the forms of their languages.

Those languages are clear for their own producer and it must be so for the users of those elements ${ }^{16}$. We call it in general relations and data. So, we consider different types of relations and data: the ancient book data produced its own languages and codifications in the past; the main relations found between information and the information itself created or detected by academic experts today; the context itself where this data was produced; the data from each chronological and geographical ambit; the data info about transformations and signs of use and appropriation; and basic and main data that supports the reports and publications where it was based on.

Added to this scenario we consider too facilitating access to that information, also by the idiomatic subject because the information was, is and will be produced in different idioms and its variations between locations. It also happens with the programming languages. In Internet there is a lot of information that can't be understood by those conditions-the idioms and programming languages-and, paradoxically, by the access to an amount of data today we can say there is a lot of data that can't be appropriated.

We found terminological variables talking about past repairs in medieval books research (Vargas, 2017). This forces us to extend our research in the terminology aspect of the ancient books documentation to solve the problematic issue about the interpretative aspects of physical description. The graphic below shows our results linking parts of the book with the language of the bibliography found with information about it, some of them today not plainly comprehended without context.

We also find that the ease of access to information has another level of complexity. It is one of the restrictions of diverse nature: rights of use and intellectual property, closed or obsolete information management systems, quality and parameters of poor reproductions, to mention a few (Montes, 2006). All those conditions affect the data access and the data management projects because some critical information is inaccessible today.

\section{Finding the parametrization, relations and algorithms: what does it means?}

The conceptual considerations for the use of AI applied to an information management system, around the subject of artistic bindings with the characteristics we have mentioned, are based on a strategy of identification and parameterized description of 
the basic elements ${ }^{17}$ of artistic bindings, the forms and typical characteristics of each decorative and functional typology, and, in turn, of each type of binding and part of the book that each discipline and field related to it has contemplated.

AI already uses body and voice patterns in humans to do a recognition process, identifying and distinguishing individuals from one another. The same strategy can be used to the AI applied in books recognition: using the huge information of patterns recognized by book archaeologists, bookbinders, book conservators and restorers, philologists, codicologists and documentation science experts in artistic historical bookbindings, the design of the main generalized characteristic of each structural component for every type of artistic historical bookbinding can be done.

There are already bookbinder styles characterized ${ }^{18}$. That information must be crossed with the main physical aspects of the book in order to identify if it is a rebinding case of a previous manuscript or impression or is a natural decoration of the book compatible with the book or codices production era. The result must be the compatibility or not between the decorative style and the book impression or manuscript dating.

The cataloguers in national libraries or heritage information units will have a support tool as thesaurus or cataloging and classification handbooks to identify the physical aspects of the library collections. At the same time, conservators and restorers will also have this helpful tool to understand the many tensions and modified structures of the books that they must treat. The historians, codicologists, paleographers, philologists and textual criticism experts could find that information compatible with their researches.

But to get there it is necessary to determine the basic forms and functions of each type of book. Using an automated description with AI, the user can submit a photography, a textual description, a video or an illustration of the main characteristics of the book in the software. The video record of the book is preferred, because in this kind of register, the AI process can detect, with stop motion, more aspects of the book than on photography. Furthermore, the AI process can grasp the shines of the burnish skin, blind or gold tooling or the iron clasps or any other materials and decoration techniques. It also can recognize the inherent sound or lack of opening of the book by some structures, when the book has its own natural or a rebinding tension, provoked by later decisions of some sellers or collectors.

Today we can say that these kinds of information are produced only by direct human recognition. In some cases, either a photo sent by mail or found in a repository is enough to do it. In many cases the use of a very good sequence of photos was necessary, as descriptions from the consult were made as well. The recognition of those patterns can be done with AI, but nobody has done this software yet in order to apply it to this kind of objects. We thought this process can be used to any other kind of cultural heritage objects in libraries, as happens with museums and architectonic heritage. The software must be developed focusing on that task. 


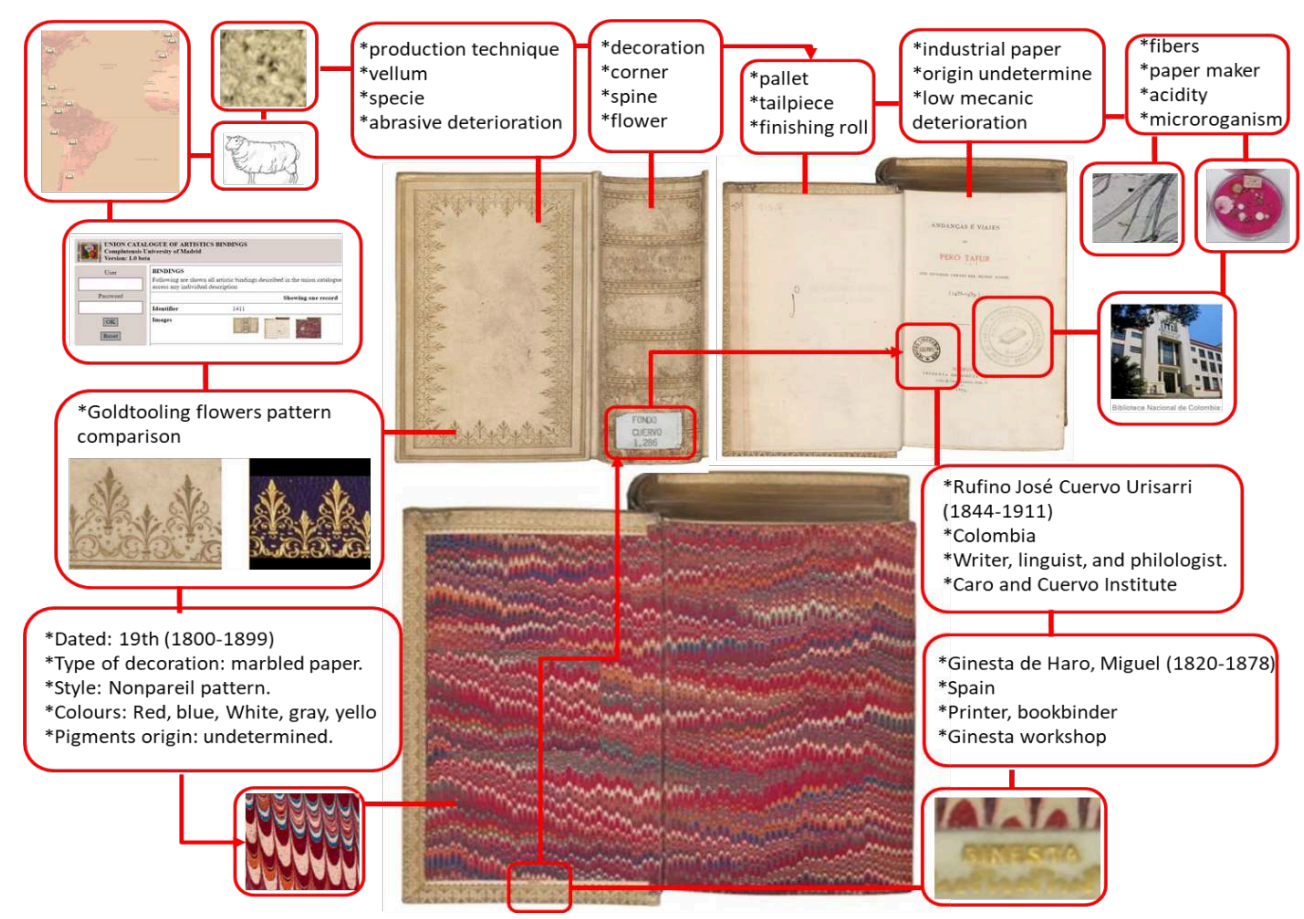

Figure 1 - This illustration shows some of the variety and different relations that can be done between artistic historical bookbinding's characteristics and fields of study. All possible relations haven't been done by anyone yet. Digital images of the bookbinding made by the National Library of Colombia.

By this way the experts can focus on the academic research and the validation task, and the AI will help access this information. Today we find patterns of issues, follicle of parchment and dyed skins from different species, water marks of ancient papers, sewing types from different kinds of techniques, quires compositions, and calligraphy and ductus patterns, to mention some examples of books elements that can now be used in the software programming.

The software programming needs the algorithms design. This process is made possible by crossing the main and principal structures of the books from the past, and with the continued ingestion of data and validation of it, which allows the automated recognition and description made by the software.

\section{Conclusions}

Without having an answer for all the problematic issues that are generated in a work of this magnitude, we propose that it is fundamental to start from the idea of communication, as an articulating axis, useful to design, taking into account the following aspects: overcoming the isolation of the disciplines and of the information produced; encouraging multidisciplinary articulation; contributing to the collective construction of information; making the information open data to be easily accessible; to ensure heritage entities that custody and manage historical sources through the information and documentation sciences, design and consider future information needs. We could encourage prospective exercises to solve those future information needs, looking at what is being developed in the field of digital humanities. Moreover it is necessary to consider in the conceptual design that information is collected to facilitate access and consultation; and data will need to be accessed from and in several 
languages, without forgetting to take into account the historical contextualization of the academic origin that recognized or formulated them.

The possibilities of interaction of the humanities in the local digital field have been expanded, but with the virtual spaces they were enhanced to the point that the very way of advancing research processes is being absorbed by the computer media making the research exercise an even more complex space. While the challenges faced by researchers enhance the possibilities of linking information, there are few means to disseminate and interconnect even more data niches. We are all creating data, but how can we get that information interrelated?

Finally, we can say that the circumstances that influence the difficulty of studying the historical artistic bindings are evident in the ignorance and lack of interest in them as a field of study and as historical sources. This generates loss, elimination or either partial or total alteration of their parts destroying the possibility of study today and in the future; the disappearance or dispersion of sources created by the same entity or chronological or topical source due to historical events and the inaccessibility of the original documents for their physical analysis. It also leads to the incomprehension of the information they offer as historical evidence not yet interpreted by historical research. At the same time, it happens with the study and partial registration of the information they contain, because of the ignorance of their informative values, for future research and the limited articulation of this aspect with respect to others and between fields of study.

\section{BIBLIOGRAPHY}

CARPAllo Antonio (2001), Análisis documental de la encuadernación española (Thesis), Complutensis University of Madrid, Madrid, Spain.

GEARY Patrick (1994), Phantoms of remembrance, New Jersey, USA: Princeton University Press.

MARTínez MANZANo Teresa (2014), “Creta y el itinerario de los textos griegos hacia occidente. El caso de los manuscritos de Matteo Dandolo”, Scripta (7), 159-184, <https://www.academia.edu/ $37781062 /$

_Creta_y_el_itinerario_de_los_textos_griegos_hacia_Occidente._El_caso_de_los_manuscritos_de_Matteo_Dandolo_Scripta_7_2014_159

Montes Doncel Rosa E. \& Rebollo Ávalos M. José (2006), “La intertextualidad (1967-2007). El largo

periplo de un término teórico", Alfinge (18), 157-180, <http://hispadoc.es/ejemplar/184638> (12

january 2019).

PIÑA LANDABURU Zuriñe (2016, noviembre), “Aplicación de los principios de las ontologías a la recuperación de información en Big Data”, V Seminario Hispano Brasileño de investigación en Información, Documentación y Sociedad, Universidad Complutense de Madrid y Universidade de Brasília, <https://www.researchgate.net/publication/

318099347_Aplicacion_de_los_principios_de_las_ontologias_a_la_Recuperacion_de_Informacion_en_Big_Data>. 
ROJAS CASTRO Antonio (2013), “Las Humanidades Digitales: principios, valores y prácticas”, JANUS (2), 74-99, <http://www.janusdigital.es/articulo.htm?id=24> (3 december 2018).

SzIRMAI Ján Alexander (1999), The Archaeology of Medieval Bookbinding, Aldershot: Ashgate.

UsATEgui BASOZABAL Elisa (1992), "La sociolingüística de Basil Bernstein y sus implicaciones en el ámbito escolar”, ESTUDIOS Revista de educación (298), 163-197, <https://sede.educacion.gob.es/ publiventa/detalle. action?cod $=486>(18$ october 2018$)$.

VARGAS MejíA María Helena (2017), Las reparaciones “de época” en libros medievales (Thesis), University of Lleida, Spain.

Zoss Angela (2013), “Data Visualization: About Data Visualization”, online at Duke University Libraries: <https://guides.library.duke.edu/datavis>.

\section{NOTES}

1. We use the expression "ancient book" referred to the books produced since Medieval Age to XIX century.

2. We found philologists, historians and restorers interested on this information. Some of them where cited in this text.

3. The Codicology or Archaeology of the Book as fields of research, mainly interested on the physical identification of the characteristics of the ancient books, reveal important data about origins of the supports, materials and techniques used, to comprehend where the ancient books came from and how they were made.

4. Since the Archeology of the Book was born as a field of study, the physical aspects were studied in greater detail and it can be said that the binding is recognized, with Szirmai and codicology, as a permanent source of information.

5. It is believed that, because it was not part of the matters considered important for its documentation in the Middle Ages, or that this was a matter of a sacred office and that should be jealously guarded, the activity related to the binding was not explicitly registered. Interpreting Szirmai (1999), we know that the impact of the loss of these evidences for the present and future study is incalculable, as has been proven, and happens with other types of loss of vestiges (Geary, 1994: 14-15).

6. Our research on the subject of the past repairs of the ancient book-associated with the subject of the materiality and transformations of the book-, suggests the existence of the office of repairer of books. We have evidence of its later existence through the records found in the Chapter Archive of Murcia and the General Archive of the Nation of Colombia, and through firsthand information received from Francisco Reyes Marsilla del Pascual-Professor of Paleography, Diplomatics, Sigilography and Codicology and Angelica Avella-Restorer and research assistant, respectively.

7. Rojas mentions the importance and the necessity of the multidisciplinary cooperation in the development of informatic tools in HD centers.

8. Today it can be found that historical artistic bindings are still described in their most basic aspects by the areas that administer the organization and access to information in libraries and information units.

9. We took the concept of contextual level and conceptual domain, referring to the impossibility of understanding the information available for lack of context and theoretical frameworks necessary to have a broader meaning and linked to other concepts and issues in which the information is embedded. 
10. Currently we are developing a scalable and interoperable descriptive module design, to work with several systems, on material aspects and codicological and bibliographic issues that could be embedded in the catalogs and repositories. We hope this design will be nurtured with the contributions of this project, regarding the AI use and the loading phase of automated descriptions data.

11. Union Catalogue of Artistics Bindings of the Complutensis University of Madrid, EU bookbinding catalogue, EAPM Association of European Printing Museums.

12. While it is true that the humanist works in the company of his peers during the review process and talks at all times with the previous tradition, their intellectual activity, the work environment and the pace of production can't be more opposed to the practices of the scientific community, according to Willard McCarty (2005: 12).

13. We found in Ligatus Research Centre a specific interest in this topic: <https:// www.arts.ac.uk/research/research-centres/ligatus> (19 June 2019).

14. We believe that Helena Bermúdez Sabel, in her introductory section to the course "Close and Distant Reading" of the UNED, refers to it clearly when she says computational methods applied to objects of study of the Humanities that can't be boarded by a human being (big data).

15. We referred the code constructions based on the sociologic context presented by Elisa Uscategui (1992) and Zuriñe P. Landaburu (2016).

16. For example, today's philologists codification used to make references of a text tradition.

17. According to what I understood about the introduction made to the subject by Alejandro Álvaro Ramírez Acosta in his conference "Inteligencia Artificial en la indexación a gran escala de librerías digitales y multimedia": <https://www.rtvc.gov.co/noticia/inteligencia-artificial-enrtvc-conozca-como-hacer-registros-gran-escala-en-librerias> (19 June 2019).

18. For example, Aldo Manuzio, Elzevirs, Ginesta, Dusseuil books decoration styles to mention only a few ones.

\section{ABSTRACTS}

The article presents the idea of a project to manage the scattered and various information about artistic historical bookbindings. It exposes the reasons why the study of the ancient book is permanent and why their study and comprehension are a difficult task. It encourages to overcome the isolation of the disciplines that study it, suggesting the multidisciplinary articulation and considering the terminology topic to collect diverse and scattered data. To carry on the project, the text proposes the automated description of artistic historical bookbindings as a digital humanities strategy, to articulate the multiple data detected and produced by researchers of diverse and multiple disciplines. The strategy presents basic considerations to the use of artificial intelligence (AI) to manage the vast quantity of information unlinked from separated fields, considering the importance to link data to their context-past chronological and geographical origins, and from the discipline that generated it-making easier the interpretation of information from other areas or perspectives of study or for the future use of the data.

Cet article présente un projet prétendant récolter les informations - éparses et variées - liées à la question des reliures artistiques et historiques. Il expose les raisons pour lesquelles l'étude des livres anciens - champ d'investigation continuant à susciter l'intérêt de beaucoup de chercheurs - et leur compréhension se révèlent être une tâche ardue. Il invite à dépasser 
l'isolement des disciplines consacrées à l'examen de ces témoignages vénérables en laissant une place plus importante à l'interdisciplinarité. Afin de mener à bien ce projet, l'auteur de l'article suggère de considérer la description automatisée des reliures comme l'un des outils des humanités numériques.

El artículo trata sobre la idea de crear un proyecto con el que se pueda recopilar información variada y dispersa en torno a las encuadernaciones artísticas históricas. En el texto, se exponen las razones por las cuales el estudio y la compresión del libro antiguo es una tarea difícil y está en permanente construcción. Además, reflexiona sobre la articulación multidisciplinar e insta a que sea un tema que se aborde desde esa manera, para evadir el aislamiento de las especialidades. Esto se plantea desde el asunto terminológico, ya que se percibe como aspecto fundamental para recopilar datos dispersos y diversos que se encuentran y producen en torno a estas encuadernaciones desde diferentes ámbitos académicos y teóricos. El artículo propone desarrollar el proyecto mediante la descripción automatizada de las encuadernaciones artísticas históricas, como estrategia viable a ser desarrollada en el ámbito de las humanidades digitales, para articular múltiples datos detectados y producidos por investigadores de diversas disciplinas. Abordando la propuesta desde esta estrategia se presentan aspectos básicos del uso de inteligencia artificial (IA) para manejar la vasta y diversa cantidad de información que se encuentra tradicionalmente desarticulada. Se resalta que dicha información debe permanecer ligada a su contexto - orígenes de su pasado cronológico y geográfico, y el de la disciplina desde donde surge - facilitando la interpretación de la información por parte de otras áreas u otras perspectivas de estudio, o para el uso libre de estos datos a futuro.

\section{INDEX}

Mots-clés: reliures artistiques historiques, pluridisciplinarité, recherche, données ouvertes, intelligence artificielle, humanités numériques, reliures « d'époque », restauration des livres antiques

Palabras claves: encuadernaciones artísticas históricas, multidisciplinariedad, datos abiertos, inteligencia artificial, humanidades digitales, reparaciones 'de época', restauración del libro antiguo

Keywords: artistic historical book binding, multidisciplinary, research, open data, artificial intelligence, digital humanities, past repairs, ancient book restoration

\section{AUTHOR}

\section{MARÍA HELENA VARGAS MEJÍA}

Universidad Complutense de Madrid 